\title{
Multidrug resistance-selective antiproliferative activity of Piper amide alkaloids and synthetic analogues
}

\author{
Yue-Hu Wang a,b, ${ }^{\text {, }}$, Masuo Goto ${ }^{a}$, Li-Ting Wang ${ }^{a}$, Kan-Yen Hsieh ${ }^{a}$, Susan L. Morris- \\ Natschke $^{a}$, Gui-Hua Tang ${ }^{c}$, Chun-Lin Long ${ }^{b, d}$, and Kuo-Hsiung Lee ${ }^{a, e,{ }^{*}}$ \\ aNatural Products Research Laboratories, UNC Eshelman School of Pharmacy, University of \\ North Carolina, Chapel Hill, NC 27599, United States \\ bKey Laboratory of Economic Plants and Biotechnology, Kunming Institute of Botany, Chinese \\ Academy of Sciences, Kunming 650201, People's Republic of China \\ 'School of Pharmaceutical Sciences, Sun Yat-sen University, Guangzhou 510006, People's \\ Republic of China
}

${ }^{d}$ College of Life and Environmental Sciences, Minzu University of China, Beijing 100081, People's Republic of China

${ }^{e}$ Chinese Medicine Research and Development Center, China Medical University and Hospital, Taichung 40447, Taiwan

\begin{abstract}
Twenty-five amide alkaloids (1-25) from Piper boehmeriifolium and 10 synthetic amide alkaloid derivatives (39-48) were evaluated for antiproliferative activity against eight human tumor cell lines, including chemosensitive and multidrug-resistant (MDR) cell lines. The results suggested tumor type-selectivity. 1-[7-(3,4,5-Trimethoxyphenyl)heptanoyl]piperidine (46) exhibited the best inhibitory activity $\left(\mathrm{IC}_{50}=4.94 \mu \mathrm{M}\right)$ against the P-glycoprotein (P-gp)-overexpressing KBvin MDR sub-line, while it and all other tested compounds, except 9, were inactive ( IC $\left._{50}>40 \mu \mathrm{M}\right)$ against MDA-MB-231 and SK-BR-3. Structure-activity relationships (SARs) indicated that (i) 3,4,5-trimethoxy phenyl substitution is critical for selectivity against KBvin, (ii) the 4-methoxy group in this pattern is crucial for antiproliferative activity, (iii) double bonds in the side chain are not needed for activity, and (iv), in arylalkenylacyl amide alkaloids, replacement of an isobutylamino group with pyrrolidin-1-yl or piperidin-1-yl significantly improved activity. Further study on Piper amides is warranted, particularly whether side chain length affects the ability to overcome the MDR cancer phenotype.
\end{abstract}

\footnotetext{
(C) 2014 Elsevier Ltd. All rights reserved.

*Corresponding authors. Tel.: +1 919962 0066; fax: +1 9199663893 (K.H.L.); tel./fax: +86 087165223318 (Y.H.W.). khlee@unc.edu. (K.H.L.), wangyuehu@mail.kib.ac.cn (Y.H.W.).

Publisher's Disclaimer: This is a PDF file of an unedited manuscript that has been accepted for publication. As a service to our customers we are providing this early version of the manuscript. The manuscript will undergo copyediting, typesetting, and review of the resulting proof before it is published in its final citable form. Please note that during the production process errors may be discovered which could affect the content, and all legal disclaimers that apply to the journal pertain.

Supplementary data

Supplementary data (experimental details and compound characterization for all synthesized compounds) associated with this article can be found, in the online version, at http:
} 


\section{Keywords}

Piper; Piperaceae; Amide alkaloids; Cytotoxicity; Multidrug resistance

The genus Piper (Piperaceae) contains approximately 2000 plant species distributed mainly in tropical areas. ${ }^{1}$ Among them, 10 Piper species have been used in traditional medicines to treat cancer or cancer-like symptoms. ${ }^{2}$ Amide alkaloids, phenylpropanoids, lignans, neolignans, terpenes, steroids, kawapyrones, piperolides, flavonoids, and alkenylphenols have been isolated from Piper plants, ${ }^{3-7}$ and amide alkaloids are the major cytotoxic constituents. $^{2}$ Especially, piplartine (piperlongumine, Figure 1) exhibits the most promise showing broad-spectrum cytotoxicity against cancer cell lines in vitro. Furthermore, it also demonstrated excellent anticancer activity in vivo. ${ }^{8,9}$ The amide alkaloids in Piper plants are usually constructed from acyl and amino moieties. The acyl moiety includes mainly alkylacyl, alkenylacyl, arylalkylacyl, and arylalkenylacyl groups. The amino moiety is generally either isobutylamine, pyrrolidine, piperidine, pyrrole, 5,6-dihydropyridin-2(1H)one, or arylethylamine. In our previous study, several amides (3-7, and 11, Figure 2) with cytotoxic activity against the human cervical carcinoma HeLa cell line were isolated from $P$. boehmeriifolium Wall. The active amides belong to the arylalkenylacylpyrrolidine classification and 1-[(9E)-10-(3,4-methylenedioxyphenyl)-9-decenoyl]pyrrolidine (7) exhibited the best inhibitory activity with an $\mathrm{IC}_{50}$ of $7.78 \mu \mathrm{M} .{ }^{10}$ However, the structureactivity relationships (SARs) of these amides against cancer cells remain unclear. In the present study, 25 amide alkaloids (1-25, Figure 2) from P. boehmeriifolium and 10 synthetic amide alkaloid analogues (39-48) were evaluated for cytotoxicity against lung adenocarcinoma A549, nasopharyngeal carcinoma KB, P-glycoprotein (P-gp)overexpressing MDR KB (KBvin), androgen insensitive prostate cancer DU145, and four breast cancer cell lines, including triple-negative [ER $\left.{ }^{-} / \mathrm{PgR}^{-} / \mathrm{erbB} 2(\mathrm{HER} 2)^{-}\right] \mathrm{MDA}-$ MB-231, triple-positive ZR-75-1, double-positive expressing multidrug resistanceassociated protein (MRP) 1 MCF-7, and HER2-overexpressing SK-BR-3 cell lines. The SARs and selective antiproliferative activity against KBvin are discussed.

Natural amide alkaloids (1-25) were obtained from the whole plant of $P$. boehmeriaefolium in our recent study. ${ }^{10}$ From results of their cytotoxic evaluation (Table 1), both an arylalkenylacyl side chain and pyrrolidin-1-yl moiety were necessary for antiproliferative activity. To determine whether double bonds in the arylalkenylacyl side chain affected activity, ten new amide alkaloids (39-48) were synthesized (Scheme 1). 3,4,5-

Trimethoxybenzaldehyde (26) was selected as the starting material to synthesize promising amide piplartine analogues. Ethyl (E)-3-(3,4,5-trimethoxyphenyl)acrylate (27) was obtained from 26 by $2 \mathrm{C}$-Wittig homologation with (carboethoxymethylene)triphenylphosphorane in benzene at reflux. ${ }^{11}$ The esters $\mathbf{2 7}, \mathbf{2 9}$, and $\mathbf{3 4}$ were reduced with diisobutylaluminum hydride to afford alcohols $\mathbf{2 8 ,} \mathbf{3 0}$, and $\mathbf{3 5}$, respectively, ${ }^{12-13}$ while alcohol $\mathbf{3 3}$ was obtained by reduction of acid $\mathbf{3 2}$ using lithium aluminium hydride. ${ }^{14}$ Acid $\mathbf{3 2}$ was produced by hydrolysis of ester 27 with lithium hydroxide in a terahydrofuran (THF) and water (2:1) mixture. ${ }^{15}$ The alcohols $\mathbf{2 8 , 3 0 , 3 3 , 3 5}$, and $\mathbf{3 7}$ were oxidized using the Parikh-Doering reaction with sulfur trioxide pyridine complex, dimethyl sulphoxide, and triethylamine and then subjected to Wittig reaction to yield esters $29, \mathbf{3 1}, \mathbf{3 4}, \mathbf{3 6}$, and 38, respectively. ${ }^{16}$ Esters 
31, 36, and 38 were hydrolyzed with lithium hydroxide in THF:water (2:1) to yield the corresponding acids. Reaction of these acids with pyrrolidine and thionyl chloride gave amides 39,41 , and 43 , and with piperidine gave amides 40,42 , and 44 , respectively. ${ }^{17}$ Hydrogenation of 35, 41, and $\mathbf{4 4}$ with hydrogen gas at 50 psi yielded $\mathbf{3 7}, \mathbf{4 5}$ and $\mathbf{4 6}$, respectively, ${ }^{18}$ and selective de-4'-O-methylation of $\mathbf{4 3}$ and $\mathbf{4 4}$ using aluminium trichloride gave $\mathbf{4 7}$ and $\mathbf{4 8}$, respectively. ${ }^{9}$

The cytotoxic activity was determined by the sulforhodamine B (SRB) colorimetric assay as previously described. ${ }^{19}$ As shown in Table 1 , the natural (1-3, and 7-10) and synthetic (4346) alkaloids showed cytotoxic activity against at least one of the eight human tumor cell lines (Table 1). Within the natural products (1-25), compounds 3 and 7-10 exhibited weak and broad spectrum activity against all tumor cell lines tested except MDA-MB-231 and SK-BR3. Compounds 1 and 2 were inactive $\left(\mathrm{IC}_{50}>40 \mu \mathrm{M}\right)$ against four types of breast cancer cell lines. Interestingly, none of the compounds except 9 were active against MDAMB-231 and SK-BR-3, suggesting tumor type-selective antiproliferative activity. Compared with the natural products, the synthetic amides $\mathbf{4 3 - 4 6}$ showed better cytotoxic activity against KBvin cells. 1-[7-(3,4,5-Trimethoxyphenyl)heptanoyl]piperidine (46) was the most active analog against KBvin cells $\left(\mathrm{IC}_{50}=4.94 \mu \mathrm{M}\right)$. P-glycoprotein $(\mathrm{P}-\mathrm{gp})$-overexpressing KBvin was sensitive to the synthetic analogs (43-46), while chemosensitive cell lines, including parental cell line $\mathrm{KB}$, were tolerant. Compound $\mathbf{4 4}$ showed the best selective index (3.8-fold selective) against MDR sub-line KBvin compared with parental KB. It is obvious that the 3,4,5-trimethoxy groups in the phenyl ring of the synthetic compounds increase the selectivity. Multidrug resistance-associated protein 1 (MRP1)-expressing MCF-7 was also tolerant to amides $\mathbf{4 3 - 4 6}$, suggesting that these analogs may be selectively cytotoxic to MDR cells overexpressing P-gp.

Double bonds in the side chain might decrease the cytotoxic activity, because compounds 39-42 were inactive against the tested cell lines. Compounds $\mathbf{4 7}$ and $\mathbf{4 8}$ were inactive, implying that a 4-methoxy group, rather than 4-hydroxy group, in the 3,4,5-trisubstituted phenyl ring is necessary for activity. Compared with amides $\mathbf{1}$ and $\mathbf{2}$, amides $\mathbf{1 2}$ and $\mathbf{1 3}$ were inactive indicating that pyrrolidin-1-yl derivatives are more potent than isobutylamino derivatives, while both pyrrolidin-1-yl (43 and $\mathbf{4 5}$ ) and piperidin-1-yl (44 and $\mathbf{4 6})$ groups are acceptable for activity.

In conclusion, arylalkenylacylpyrrolidines $(\mathbf{1 - 3 , 7 - 1 0 , 4 3 )}$, an arylalkylacylpyrrolidine (45), an arylalkenylacylpiperidine (44), and an arylalkylacylpiperidine (46) showed inhibitory activity against at least one of eight tested human tumor cell lines. Double bonds in the side chain were not needed for activity. 3,4,5-Trimethoxy substitution in the phenyl ring of the amide alkaloids increased selectivity against MDR sub-line KBvin, while the 4-methoxy group in this pattern is required for cytotoxic activity. These results demonstrate that newly synthesized amide alkaloids show tumor type-selective antiproliferative activity, especially against MDR cells. These synthesized analogues may target a unique protein that is highly responsible for the proliferation of KBvin, while dispensable in chemosensitive cell lines, such as SK-BR-3 and MDA-MD-231. Compounds, such as verapamil and desmosdumotin B analogues, ${ }^{19}$ that show at least a two-fold selective cytotoxicity against MDR cells are called collateral sensitivity (CS) agents. ${ }^{20}$ Although their mechanisms of action are largely unclear, 
CS agents are expected to be a new class of chemopreventive adjuvant for cancer chemotherapy to suppress development of MDR phenotype. ${ }^{21}$ Thus, it is worthwhile to conduct further SAR study of Piper amides, including the effect of the side chain length on the activity of these amide alkaloids against cancer cells showing the MDR phenotype.

\section{Supplementary Material}

Refer to Web version on PubMed Central for supplementary material.

\section{Acknowledgments}

This work was supported by the by the Natural Science Foundation of Yunnan Province, China (No. 2011FZ205). Thanks are also due to partial support from NIH grant CA177584 from the National Cancer Institute awarded to K. H. Lee.

\section{References and notes}

1. Tseng, YC.; Xia, NH.; Gilbert, MG. Flora of China. Vol. 4. Beijing/St. Louis: Science Press/ Missouri Botanical Garden Press; 1999. p. 110

2. Wang YH, Morris-Natschke SL, Yang J, Niu HM, Long CL, Lee KH. J. Tradit. Complement. Med. 2014; 4:8. [PubMed: 24872928]

3. Yang SX, Sun QY, Yang FM, Hu GW, Luo JF, Wang YH, Long CL. Planta Med. 2013; 79:693. [PubMed: 23576174]

4. Scott IM, Jensen HR, Philogene BJR, Arnason JT. Phytochem. Rev. 2008; 7:65.

5. Parmar VS, Jain SC, Bisht KS, Jain R, Taneja P, Jha A, Tyagi OD, Prasad AK, Wengel J, Olsen CE. Phytochemistry. 1997; 46:597.

6. Kato MJ, Furlan M. Pure Appl. Chem. 2007; 79:529.

7. Liu HX, Chen K, Sun QY, Yang FM, Hu GW, Wang YH, Long CL. J. Nat. Prod. 2013; 76:732. [PubMed: 23544451]

8. Bezerra DP, Pessoa C, de Moraes MO, Saker-Neto N, Silveira ER, Costa-Lotufo LV. Eur. J. Pharm. Sci. 2013; 48:453. [PubMed: 23238172]

9. Raj L, Ide T, Gurkar AU, Foley M, Schenone M, Li XY, Tolliday NJ, Golub TR, Carr SA, Shamji AF, Stern AM, Mandinova A, Schreiber SL, Lee SW. Nature. 2011; 475:231. [PubMed: 21753854]

10. Tang GH, Chen DM, Qiu BY, Sheng L, Wang YH, Hu GW, Zhao FW, Ma LJ, Wang HA, Huang QQ, Xu JJ, Long CL, Li J. J. Nat. Prod. 2011; 74:45. [PubMed: 21158422]

11. Sabitha G, Srinivas C, Reddy TR, Yadagiri K, Yadav JS. Tetrahedron-Asymmetr. 2011; 22:2124.

12. Purushotham Reddy S, Venkateswarlu Y. Tetrahedron Lett. 2013; 54:4617.

13. Preuss T, Saak W, Doye S. Chem.-Eur. J. 2013; 19:3833. [PubMed: 23426885]

14. Laurent MY, Stocker V, Temgoua VM, Dujardin G, Dhal R. Tetrahedron Lett. 2011; 52:1608.

15. Rao VR, Muthenna P, Shankaraiah G, Akileshwari C, Babu KH, Suresh G, Babu KS, Kumar RSC, Prasad KR, Yadav PA, Petrash JM, Reddy GB, Rao JM. Eur. J. Med. Chem. 2012; 57:344. [PubMed: 23124161]

16. Yang X, Shi Q, Lai CY, Chen CY, Ohkoshi E, Yang SC, Wang CY, Bastow KF, Wu TS, Pan SL, Teng CM, Yang PC, Lee KH. J. Med. Chem. 2012; 55:6751. [PubMed: 22823514]

17. Thota N, Koul S, Reddy MV, Sangwan PL, Khan IA, Kumar A, Raja AF, Andotra SS, Qazi GN. Bioorgan. Med. Chem. 2008; 16:6535.

18. Lin L, Shi Q, Nyarko AK, Bastow KF, Wu CC, Su CY, Shih CCY, Lee KH. J. Med. Chem. 2006; 49:3963. [PubMed: 16789753]

19. Nakagawa-Goto K, Chang PC, Lai CY, Hung HY, Chen TH, Wu PC, Zhu H, Sedykh A, Bastow KF, Lee KH. J. Med. Chem. 2010; 53:6699. [PubMed: 20735140]

20. Hall MD, Handley MD, Gottesman MM. Trends Pharmacol. Sci. 2009; 30:546. [PubMed: 19762091] 
21. Pluchino KM, Hall MD, Goldsborough AS, Callaghan R, Gottesman MM. Drug Resist. Update. 2012; 15:98. 


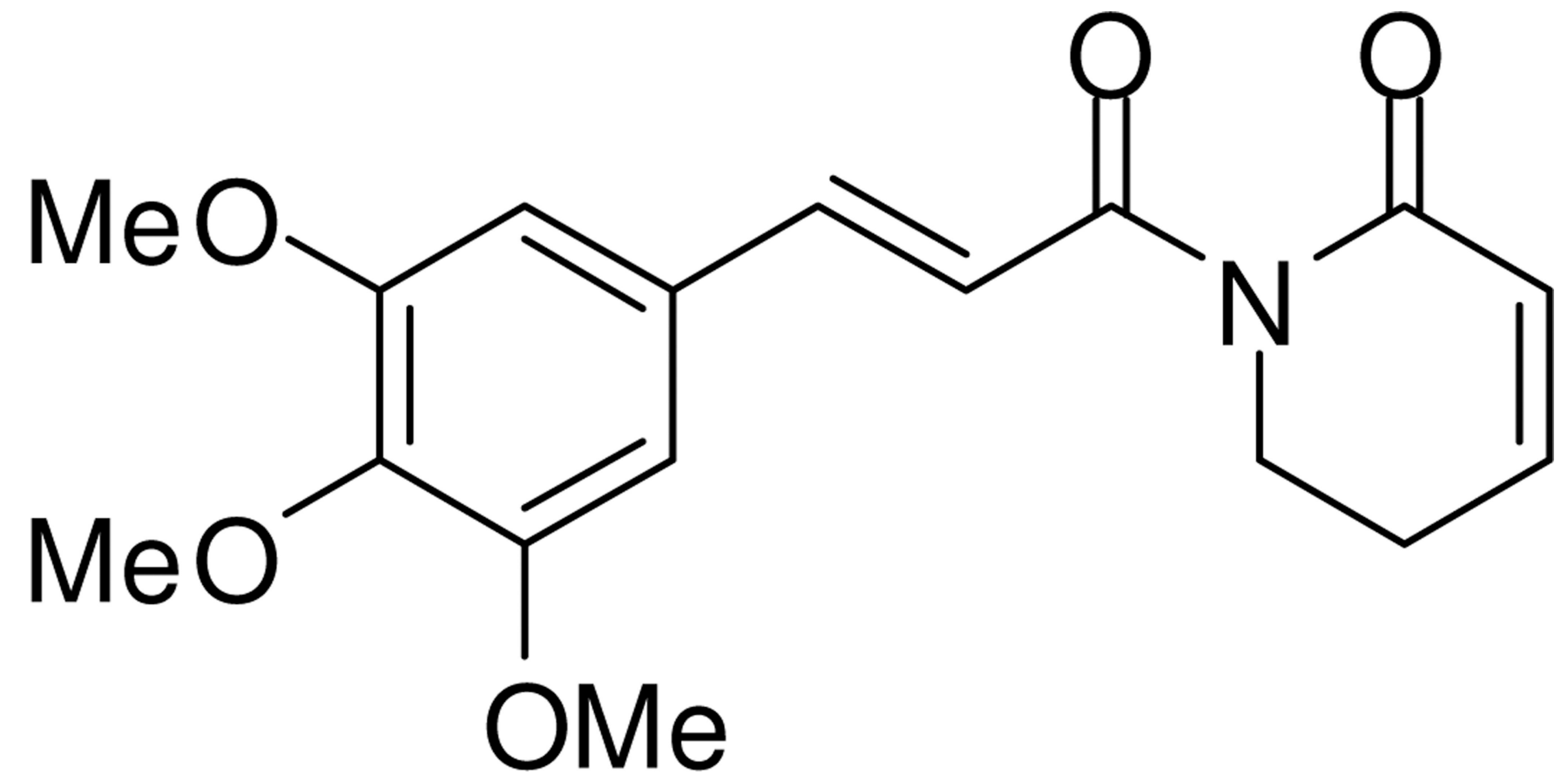

Figure 1.

The structure of piplartine (piperlongumine). 
<smiles>[R]C(=O)/C=C/[AlH]Cc1ccc2c(c1)OCO2</smiles><smiles>[R]C(=O)/C=C/C=C/C[Te]c1ccc2c(c1)OCO2</smiles>

$13 \mathrm{R}=$ isobutylamino<smiles>O=C(/C=C/C=C/CC/C=C/c1ccc2c(c1)OCO2)N1CCCC1</smiles>

5<smiles>[R]C(=O)/C=C/C=C/[Al]C/C=C/c1ccc2c(c1)OCO2</smiles><smiles>[R]C(=O)NC/C=C/c1ccc2c(c1)OCO2</smiles>

$3 \mathrm{R}=$ pyrrolidin $-1-\mathrm{yl}$ $14 \mathrm{R}=$ isobutylamino
9<smiles>O=C(CC/C=C/[AlH2]C/C=C/c1ccc2c(c1)OCO2)N1CCCC1</smiles>

11<smiles>CC(C)C=CC=CC(=O)N1CCCC1</smiles>

17

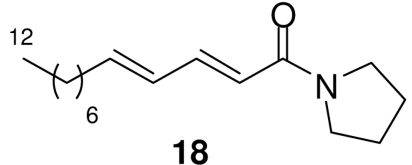

18<smiles>CCC=CC=CC=CC(=O)N1CCCC1</smiles>

19<smiles>[R]Oc1cc(CCC(=O)n2cccc2)cc(OC)c1OC</smiles>

10<smiles>[R6]c1cc(/C=C/C(=O)NCCc2ccc(O)cc2)cc([R])c1O</smiles>

Figure 2.

The structures of amide alkaloids (1-25) from Piper boehmeriaefolium. 
<smiles>CCOC(=O)/C=C/C=C/c1cc(OC)c(OC)c(OC)c1</smiles><smiles>CCOC(=O)/C=C/C=C/C=C/c1cc(OC)c(OC)c(OC)c1</smiles><smiles>COc1cc(CC/C=C/CO)cc(OC)c1OC</smiles><smiles>[R]C(=O)/C=C/C=C/C=C/c1cc(OC)c(OC)c(OC)c1</smiles><smiles>CCOC(=O)/C=C/C=C/CCc1cc(OC)c(OC)c(OC)c1</smiles>

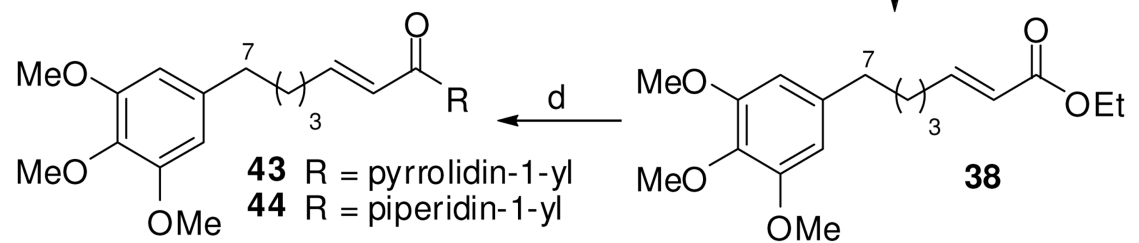<smiles>[R]C(=O)/C=C/C=C/CCc1cc(OC)c(OC)c(OC)c1</smiles><smiles>[R]C(=O)/C=C/[Al]Cc1cc(OC)c(O)c(OC)c1</smiles><smiles>[R]C(=O)NCc1cc(OC)c(OC)c(OC)c1</smiles>

Scheme 1.

Synthesis of amide alkaloids (39-48). Reagents and conditions: (a) $\mathrm{Ph}_{3} \mathrm{P}=\mathrm{CHCO}_{2} \mathrm{Et}$, benzene, refluxed, $4 \mathrm{~h}$; (b) DIBAL-H (1.0 M in THF), $\mathrm{CH}_{2} \mathrm{Cl}_{2},-50{ }^{\circ} \mathrm{C}$ to rt, $2 \mathrm{~h}$; (c) (i) $\mathrm{Py} \cdot \mathrm{SO}_{3}, \mathrm{DMSO}, \mathrm{Et}_{3} \mathrm{~N}, \mathrm{CH}_{2} \mathrm{Cl}_{2}, 0{ }^{\circ} \mathrm{C}$ to rt, $2 \mathrm{~h}$; (ii) $\mathrm{Ph}_{3} \mathrm{P}=\mathrm{CHCO}_{2} \mathrm{Et}$, benzene, refluxed, $4 \mathrm{~h}$; (d) (i) $\mathrm{LiOH} \cdot \mathrm{H}_{2} \mathrm{O}$, THF-H $\mathrm{H}_{2} \mathrm{O}(2: 1)$, rt, $36 \mathrm{~h}$; (ii) $\mathrm{SOCl}_{2}, \mathrm{CH}_{2} \mathrm{Cl}_{2}$, refluxed, $1 \mathrm{~h}$; (iii) pyrrolidine (for 39, 41, and 43) or piperidine (for 40, 42, and 44), $\mathrm{CH}_{2} \mathrm{Cl}_{2}, \mathrm{rt}, 30 \mathrm{~min}$; (e) $\mathrm{LiOH} \cdot \mathrm{H}_{2} \mathrm{O}$, THF-H $\mathrm{H}_{2} \mathrm{O}(2: 1)$, rt, $36 \mathrm{~h}$; (f) $\mathrm{LiAlH}_{4}$, THF, $0{ }^{\circ} \mathrm{C}$ to rt, overnight; (g) $10 \% \mathrm{Pd} / \mathrm{C}$, EtOAc, $\mathrm{H}_{2}, 50 \mathrm{psi}, 24 \mathrm{~h}$; (h) $\mathrm{AlCl}_{3}, \mathrm{CH}_{2} \mathrm{Cl}_{2}$, rt, 4 h. 


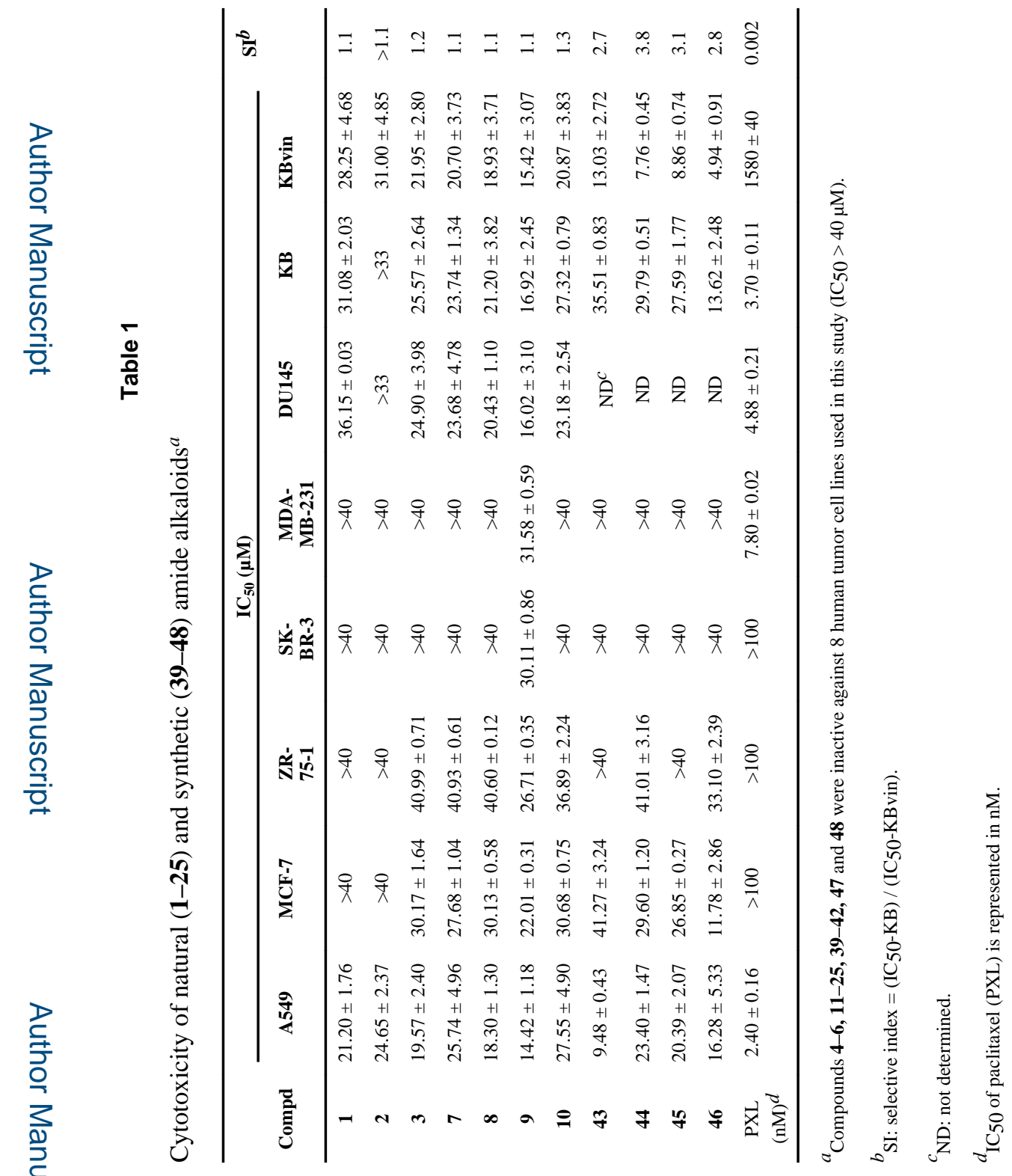

